nagyobb mértékben hajlottak arra, hogy részt vegyenek a projektben stb. Foster hangsúlyozza, hogy bár a kutatónak legyen kívülálló vagy sem - nincs lehetősége egy egész közösség teljes élményanyagának megragadására, a kisebbséghez tartozó tudósok képesek lehetnek alternatív gondolkodásmódok, új paradigmák meghonosítására és segíthetik a párbeszédet fehér és nem fehér kollégáik között.

A szerzőpáros, Gloria Ladson Billings és David Gillborn a tanulmánykötet összeállításakor arra törekedett, hogy a könyv a multikulturális oktatás témakörének egy meghatározott, részletgazdag keresztmetszetét nyújtsa. Ezen célkitüzés eredménye egy, a felépítését tekintve könnyen áttekinthető, résztémákra bontott, mégis az olvasóval a kérdéskör sok aspektusát megismertető mü, amely változatos élményanyaggal rendelkező kutatók munkáit fogja össze, és amely információval szolgál a téma számos gyakorlati implikációját illetően, miközben érinti a mindennapi iskolai élet diszkriminatív indíttatású aktusait, az önszerveződő civil mozgalmakat, a kutató szerepkörét és az eltérő kulturális hátérrel bíró szakemberek közötti párbeszédet. Ennek ellenére, mivel az egyes részek írásai eltérő fogalomkereteket, kérdésfelvetéseket, kiindulási pontokat, magyarázóelveket alkalmaznak, az olvasó részéről erőfeszítést igényel, hogy a megfogalmazott gondolatokat, eredményeket, célkitüzéseket összekapcsolja egymással, és egyetlen keretbe, a multikulturális oktatás témakörébe illessze.

Ladson-Billings, G. és David Gillborn, D. (2004, szerk.): The RoutledgeFalmer Reader in Multicultural Education. Routledge Falmer Taylor \& Francis Group, London and New York.

Hegelsberger Judit - Boreczky Ágnes ELTE, PPK, Interkulturális Pszichológiai és Pedagógiai Központ

\title{
Video Research in the Learning Sciences
}

A szerkesztốk legfóbb célként a videó mint kutatási eszköz új, teoretikus, metodikai és praktikus használatának elmélyitését és kibóvitését tüzték ki, ezzel új szemléletet adva a tanulás tudománya ('learning science') kutatási módszertanához. Arra keresték a választ, miként hasznosithatja a tanulás tudománya a videó szinte korlátlanul alkalmazható lehetóségeit. Az általuk kinált módszerek egyszerre felelnek meg tanárnak és diáknak, kutatónak és professzornak.

$\mathrm{H}$ abár a könyvet oktatáskutatási segédeszköznek szánták, bíznak benne, hogy azok a kutatók is, akik a digitális videót kutatásra használják (például a kulturális kutatások terén), úgy érzik majd, hogy hasznos számukra ez a kiadvány.

A könyv mind a 35 fejezetében nyomon követhető a szerzők által meghatározott kettős szempont: az egyik fó vonulat a videó használata a tanulás tudományában, a másik pedig a videó segítette tanítás (például osztálytermekben referátumok felvétele), illetve a videó mint tanulási-tanítási segédeszköz.

A könyv négy nagy részből épül fel, melyek közel azonos számú fejezetet tartalmaznak. Minden rész legelső fejezete a könyv egy-egy szerkesztője által írt általános bemutatása a soron következő nagy résznek, de egyben értékelés is. Az első rész a videóhasználat általános, alapvető 
elméleti keretét mutatja be. A második részben a nem formális tanulásban alkalmazható lehetőségeket veszik sorra, majd a harmadik részben a formális, osztálytermi oktatásban alkalmazható videóhasználattal ismerkedhetünk meg. A negyedik rész az aktuális és a jövőbeli technikai lehetőségek kihasználhatóságát vetíti előre a videóhasználattal kapcsolatban.

A könyv nagyon jól strukturált; a szerkesztők - említik is - külön figyelemmel ügyeltek arra, hogy megfelelően vezessék végig az olvasót ezen az összetett témán. Ez szinte elengedhetetlen, hiszen módszertani könyvről van szó. A négy rész első fejezetei különösen fontosak. A szerkesztők nemcsak bemutatják az adott fejezetet, nemcsak összefoglalják azt, hanem értékelik is, amivel kritikus gondolkodásra sarkallják az olvasót. A bevezető fejezetben található kritikai megjegyzések nemhogy zavaróak lennének, sokkal inkább ösztönzően hatnak az továbbolvasásra, miközben a szerzők még ugyanebben a részben széles körü tapasztalaton s egyúttal megfelelően szilárd elméleti alapokon nyugvó útmutatásokat is adnak a videó gyakorlatban való alkalmazása során felmerülő kérdések, kételyek, problémák megoldását illetően. A bevezetőkben személyes példákat is találunk, amelyek mégis olyannyira integráltnak hatnak, hogy az olvasóban csak tovább erősítik azt az érzést, hogy a könyv nem cikkek, fejezetek puszta egymásutánja, hanem a négy szerkesztő tudatos, egységbe szerkesztett müve.
Az első rész (Theoretical Frameworks) az egész munka elméleti kereteit fogalmazza meg. A szerzők itt mutatják be, hogy milyen lehetőségek rejlenek a videóhasználatban az ismert leíró, reprezentáló, analizáló és közvetítő szerepek mellett. Ilyen például a tanulóközösségek vagy a kultúrák. A második részben (Video Research on Peer; Family, and Informal Learning) a szerzők arra hívják fel a figyelmet, hogy a videónak mekkora szerepe van a párban vagy családi környezetben folyó tanulás és interakciók kutatásában, de ugyanígy a múzeumokban vagy különböző oktatási, technológiai intézetekben. A harmadik részben (Video Research on Classroom and Teacher Learning) bemutatják, hogy mit is profitálhatnak a tanárok és a diákok, ha a digitális videó abban segít, hogy az osztálytermekben a komplex és igazi világot lehessen bemutatni. Az utolsó, negyedik nagy részben (Video Vollaboratories and Technical Futures) pedig a videó jövőbeli használatára és előnyeire mutatnak példákat.

A Video Research in the Learning Sciences alapos, mindenre kiterjedő videóhasználati módszertani összefoglaló, mely eddig egyedülálló a piacon. Elsősorban azért, mert még nem jelent meg a videohasználat és alkalmazhatóság tárházát összefoglaló igénnyel bemutató tudományos munka, illetve még egyetlen munka sem vizsgálta ilyen alaposan a videokutatás jellemzőit a tanulás tudományában való alkalmazhatóság 
összefüggésében. A videokézikönyvek tipikusan inkább technikai, nem pedig metodikai megközelítésben mutatják be a videohasználat lehetőségeit.

Hogyan lehet egy könyvben bemutatni a videóhasználatot, amely a mozgó, hangos, élő mivolta miatt olyannyira összetett, bonyolult világ reprezentációja? A könyv bevezetőjében a szerkesztők két honlap adatait is közlik: mint azonban a recenzensek számára világossá vált, az egyik nem elérhető (www.videoresearch.org), a másik pedig (www.nyu.edu/education) messze elmarad a könyv színvonalától. A könyvben minden egyes kutatás, illetve utalás mellé megadtak a szerzők egy honlapcímet is, ám ez sem segít: a könyv mellé kétségtelenül hiányzik egy CD-ROM vagy DVD, amely nem a könyvet, hanem a technikákat, példákat mutathatná be videoprezentációk segítségével. Jelenleg tehát nincsen se videós, se virtuális változata a könyvnek, és ez sajnos olyan, mint amikor például egy jól megalkotott tanterv nincs összhangban a rejtett tantervvel.

Ugyancsak problémát jelent - ahogy arra Bhattacharya (2008) is felhívja a figyelmet -, hogy nincs önálló fejezete az etikai kérdéseknek. Ez nem azt jelenti, hogy a könyv negligálná ezt a témát, amely pedig a videókutatások kulcsfontosságú, logisztikai, de egyéb szempontokból is sok kérdést felvető eleme, ám a kérdés különféle vonatkozásai az egyes fejezetekben szétszórtan jelennek csupán meg. Minthogy azonban a videokutatásoknak maguknak az etikai kérdések tisztázásával kell kezdődniük, logikus lett volna, hogy a könyv legelején erre a kérdéskörre külön kitérjenek a szerzők.

Kell-e standardizálni a videókutatást? Ezt a kérdést boncolgatja Derry a harmadik rész bevezető fejezetében. Annak érdekében, hogy a leendő és a már praktizáló tanárok kezébe könnyen alkalmazható kézikönyvet adjunk, elengedhetetlen lenne a standardizálás. De lehet-e, szabad-e dinamikus világunkat keretek és előre meghatározott pontok közé szorítani? Ez lehetne akár magának a könyv bevezetőjének a kérdése is. A szerzők többféle meg- közelítést mutatnak be ezen a téren, ezzel is sugallva, hogy nem csupán egyetlen jó megoldás létezik: egyes helyzetekben a mozgó, más helyzetekben az álló kamera a jobb; bizonyos helyzetekben az elöre megírt, szigorú rögzítési szempont a kedvezőbb, más munkaszituációkban viszont a random felvétellel jutunk el a valósághoz. És persze létezik mindegyiknek a kevert változata is. Derry - tudományos munka esetében meglepő öszinteséggel vallja be: maga sem érti, miért - a standardizálás mellett teszi le a voksát, de a harmadik fejezetet végigolvasva elegendő támogatást kapunk a példákon keresztül, hogy magunk is ki tudjuk választani az adott helyzetnek legjobban megfelelő ,standard" felvételi formát.

Mivel a könyv sok gyakorlati példát is bemutat, a kötet ismeretében már bátran használhatják ezt a vizuális technikai lehetőséget olyanok is, akik eddig még nem próbálkoztak a videó alkalmazásával, mert nem tudták, nem merték használni, vagy egyszerüen csak nem gondoltak rá, hogy használjanak videót tanulmányaik, prezentációjuk vagy oktatásuk során. Akik pedig tapasztalt videóhasználók, azoknak a negyedik rész technikai leírásai és a jövőbeli kiterjeszthetőség nyújthat új ötleteket, a könyv második, harmadik része pedig tudományosan is megerösítheti őket a helyes úton való haladásban.

A kötet korábban már említett jól strukturáltsága miatt fejezetekre, témákra felbontva könnyen alkalmazható a tanításvagy tanulásmódszertani órák során is. A gyakorlatban való alkalmazhatósága mellett szól a fejezetekben megadott honlapok és konkrét kutatási példák újbóli kipróbálásának vagy további feldolgozásának lehetősége. A megértést segítik az ábrák, idézetek, képek, viszont csak sajnálhatjuk, hogy nem jutott pénz a színes illusztrációkra.

Mai életünkben már elképzelhetetlen, hogy csupán statikus, álló világgal vegyük körbe magunkat. A videóban pedig benne van a folytonos mozgás, történés, az aktualitás és a végtelen variálhatóság. A Video Research in the Learning Sciences már most alapvető segédeszköze a videót 
alkalmazó kutatásoknak a tanulástudomány terén, és biztosak lehetünk annak, hogy ez még hosszú ideig így marad a pedagógiai kutatások és alkalmazások szélesebb körében.
Goldman, R., Pea, R., Barron, B. és Derry, S. J. (2007). Video Research in the Learning Sciences. Lawrence Erlbaum Associates, Mahwah, NJ. 624 o. ISBN 978-0-8058-5360-5-0-8058-5360-X

\section{Irodalom}

Bhattacharya, M. (2008): Book Review - Video in Research in the Learning Sciences. International Review of Research in Open and Distance Learning, 9. 3. sz.
Páva Rita - Gordon Györi János

ELTE, PPK, Interkulturális Pszichológiai és Pedagógiai Központ

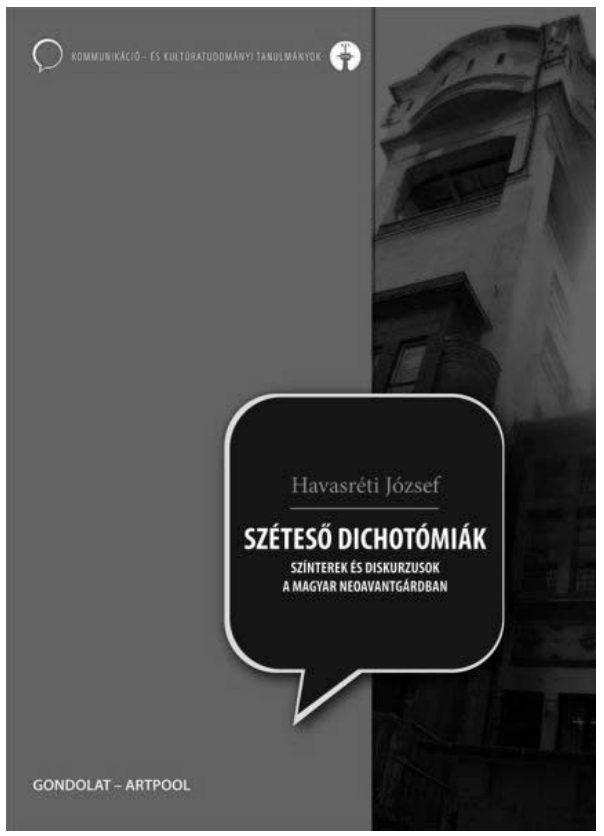

A Gondolat Kiadó könyveiböl 